\title{
Pengaruh Pendapatan Usaha, Beban Usaha, dan Bagi Hasil Pihak Ketiga terhadap Laba Usaha pada PT Bank Syariah Mandiri
}

\begin{abstract}
Author:
Laely Purnamasari

Affiliation:

STKIP PGRI Sukabumi

Corresponding Author:

Laely Purnamasari

Email:

laelyjuli74@gmail.com

Article History:

Received: March 25, 2018

Revised : April 06, 2018

Accepted: June 13, 2018

How to cite this article: Purnamasari, L. (2018). Pengaruh Pendapatan Usaha, Beban Usaha, dan Bagi Hasil Pihak Ketiga terhadap Laba Usaha pada PT Bank Syariah Mandiri. Organum: Jurnal Saintifik Manajemen dan Akuntansi, 1(1), 32-46. doi: https://doi.org/10.35138/organu $\underline{\text { m.v1i1.31 }}$
\end{abstract}

\section{Journal Homepage:}

ejournal.winayamukti.ac.id/ind ex.php/Organum

\section{Copyright:}

(C) 2018. Published by Organum: Jurnal Saintifik Manajemen dan Akuntansi. Faculty of Economics and Business. Winaya Mukti University.

\begin{abstract}
The development of operating revenue in Syariah Mandiri Bank is quiet excellent along with the increasing awareness of Muslims in using Islamic banking services. However, the development of this revenue is not accompanied by proportional increase in net operating income. This article focuses on the discussion of the relationship of operating revenue, operating expense and profit sharing of third parties and their effects on net operating income at Syariah Mandiri Bank. The purposes of this research are to describe and analyze the relationship of operating revenue, operating expense and profit sharing of third parties and their effects on net operating income both partially and simultaneously. The research method used descriptive and verification. The results showed that the operating revenue and the operating expenses had a strong relationship with the third party profit sharing. For the results of the third parties, the operating revenue and the operating expenses partially were not proven to significantly affect the net operating income but the operating revenue and the operating expenses were proven to affect the net operating income significantly. From this research, it was also known that the operating revenue component that most influenced net operating income was the mudharabah income and the operating expenses that most influenced net operating income was the loss expense for the elimination of productive assets.
\end{abstract}

Keywords: Operating revenue; operating expense; third parties profit sharing; net operating income.

Abstrak. Perkembangan pendapatan usaha pada Bank Syariah Mandiri sangat baik seiring dengan semakin tingginya kesadaran umat islam dalam menggunakan layanan perbankan syariah. Namun perkembangan pendapatan ini ternyata tidak disertai dengan kenaikan laba usaha secara proporsional. Artikel ini akan memfokuskan pada pembahasan mengenai hubungan pendapatan usaha, beban usaha dan bagi hasil pihak ketiga serta pengaruhnya terhadap laba usaha pada Bank Syariah Mandiri. Adapun tujuan penelitian ini adalah mendeskripsikan dan menganalisis hubungan pendapatan usaha, beban usaha dan bagi hasil pihak ketiga serta pengaruhnya terhadap laba usaha baik secara parsial maupun simultan. Metode penelitian yang digunakan adalah deskriptif dan verifikatif. Dalam penelitian ini akan menguji hubungan pendapatan usaha, beban usaha dan bagi hasil pihak ketiga, serta pengaruhnya terhadap laba usaha. Berdasarkan hasil penelitian dan pembahasan, dapat ditemukan bahwa pendapatan usaha dan beban usaha memiliki hubungan yang kuat dengan bagi hasil pihak ketiga. Bagi hasil pihak ketiga, pendapatan usaha dan beban usaha secara parsial tidak terbukti memengaruhi laba usaha secara signifikan namun pendapatan usaha dan beban usaha secara simultan terbukti memengaruhi laba usaha secara signifikan. Dari penelitian ini juga diketahui komponen pendapatan usaha yang paling memengaruhi laba usaha adalah pendapatan mudharabah dan beban usaha yang paling memengaruhi laba usaha adalah beban kerugian penghapusan aset produktif.

Kata kunci: Pendapatan usaha; beban usaha; bagi hasil pihak ketiga; laba usaha. 


\section{Pendahuluan}

$\mathrm{P}$ erkembangan bank syariah di Indonesia dapat dirunut dari perubahan peraturan perundangundangan yang berlaku di Indonesia. Bank syariah sebagai salah satu bentuk usaha jasa keuangan yang memiliki ciri-ciri khusus tentunya membutuhkan peraturan perundang-undangan yang khusus pula. Sejarah mencatat bahwa kehadiran bank syariah pertama ditandai dengan berdirinya Bank Muamalat tahun 1997 dan mulai menjalankan operasionalnya di tahun 1998.

Akhirnya pada tahun 1991 berdirilah Bank Muamalat sebagai bank syariah pertama di Indonesia yang dalam operasionalnya dipayungi hukum positif dengan dikeluarkannya Undang-Undang nomor 7 tahun 1992 tentang Perbankan di Indonesia yang memperkenankan digunakannnya sistem bagi hasil. Enam tahun kemudian pemerintah mengeluarkan Undang-Undang nomor 10 tahun 1998 yang memperbolehkan bank umum untuk membuka Unit Usaha Syariah (UUS). Perkembangan menggembirakan untuk perbankan syariah terjadi di tahun 2008 saat pemerintah mengeluarkan UndangUndang nomor 21 tahun 2008 tentang Perbankan Syariah yang mendorong unit usaha syariah pada bank umum untuk berdiri sendiri menjadi bank umum syariah (BUS) sehingga melepaskan diri dari belenggu sistem perbankan ganda (dual banking system).

Pada akhir tahun 2007, sebelum dikeluarkannya undang-undang perbankan syariah, di Indonesia hanya ada 3 bank umum syariah yaitu Bank Muamalat, Bank Syariah Mandiri, dan Bank Mega Syariah. Tapi pada akhir tahun 2014 jumlahnya bertambah menjadi 12 bank umum syariah. Untuk menggambarkan perkembangan perbankan syariah di Indonesia sejak tahun 2007 hingga tahun 2014 penulis merangkum perkembangannya yang dapat dilihat pada Tabel 1 .

Tabel 1. Data Perkembangan Perbankan Syariah Di Indonesia

\begin{tabular}{cccc}
\hline Tahun & $\begin{array}{c}\text { Jumlah } \\
\text { Bank Umum } \\
\text { Syariah (BUS) }\end{array}$ & $\begin{array}{c}\text { Bank umum } \\
\text { konvensional } \\
\text { yang memiliki } \\
\text { unit usaha } \\
\text { syariah (UUS) }\end{array}$ & $\begin{array}{c}\text { Bank Pembiayaan Rakyat } \\
\text { Syariah (BPRS) }\end{array}$ \\
\hline 2007 & 3 & 26 & 114 \\
\hline 2008 & 5 & 27 & 131 \\
\hline 2009 & 6 & 25 & 138 \\
\hline 2010 & 11 & 23 & 150 \\
\hline 2011 & 11 & 24 & 158 \\
\hline 2012 & 11 & 24 & 163 \\
\hline 2013 & 11 & 24 & 163 \\
\hline 2014 & 12 & 22 & 2014 \\
\hline Sumbrat
\end{tabular}

Sumber : Otoritas Jasa Keuangan, Statistik Perbankan Syariah Desember 2014

Dari 12 bank umum syariah yang ada di Indonesia, PT Bank Syariah Mandiri adalah bank umum syariah terbesar yang memiliki kantor pusat operasional, kantor cabang, kantor cabang pembantu, unit pelayanan syariah, dan kantor kas terbanyak.

Adapun tren perkembangan pendapatan usaha, beban usaha, dan laba usaha dapat dilihat pada Tabel 2. 
Tabel 2. Tren Perkembangan Pendapatan Usaha, Beban Usaha, dan Laba Usaha PT Bank Syariah Mandiri, Tahun 2008 Sampai 2014

\begin{tabular}{ccccc}
\hline Tahun & $\begin{array}{c}\text { Tren } \\
\text { Pendapatan } \\
\text { Usaha }\end{array}$ & $\begin{array}{c}\text { Tren } \\
\text { Beban } \\
\text { Usaha }\end{array}$ & $\begin{array}{c}\text { Tren } \\
\text { Bagi Hasil } \\
\text { Pihak Ketiga }\end{array}$ & $\begin{array}{c}\text { Tren } \\
\text { Laba Usaha }\end{array}$ \\
\hline 2008 & 100 & 100 & 100 & 100 \\
\hline 2009 & 119 & 110 & 117 & 151 \\
\hline 2010 & 138 & 146 & 129 & 136 \\
\hline 2011 & 146 & 145 & 153 & 147 \\
\hline 2012 & 120 & 121 & 107 & 80 \\
\hline 2013 & 114 & 131 & 109 & 11 \\
\hline 2014 & 99 & 109 & 118 & \\
\hline
\end{tabular}

Sumber : Data Olahan dari Laporan Keuangan PT Bank Syariah Mandiri (www.syariahmandiri.com)

Berdasarkan latar belakang tersebut dengan alasan PT Bank Syariah Mandiri adalah bank umum syariah dengan operasional terbesar di Indonesia dan tren perkembangan pendapatan usaha, beban usaha, dan laba usaha PT Bank Syariah mandiri yang tidak proporsional.

Pendapatan dan beban usaha tidak dapat dipisahkan, dan pendapatan adalah hasil yang dapat diperoleh dari kegiatan operasi yang dilakukan perusahaan sedangkan beban adalah biaya yang dikeluarkan atau digunakan untuk memperoleh pendapatan yang diharapkan oleh perusahaan. Perusahaan perlu memperhatikan pendapatan yang diterima dan pengeluaran yang dilakukan selama kegiatan operasi berlangsung, agar perusahaan dapat menghasilkan laba yang diinginkan demi keberlangsungan usahanya. Jika pendapatan lebih besar dari beban maka perusahaan akan memperoleh laba dan sebaliknya jika pendapatan lebih kecil dari biaya yang dikeluarkan maka perusahaan akan mengalami kerugian (Pasaribu, 2017:173). Hal ini menandakan bahwa adanya pengaruh positif antara pendapatan usaha dengan laba usaha.

Pembiayaan bagi hasil berpengaruh negatif dan signifikan terhadap laba bersih, artinya apabila pendapatan bagi hasil pembiayaan mengalami kenaikan, maka laba bersih akan mengalami penurunan. Hal ini berbeda dengan pendapatan bagi hasil yang berpengaruh positif yaitu jika pendapatan bagi hasil meningkat, maka terdapat kenaikan laba usaha (Suryandari, 2018). Berdasarkan hal tersebut menunjukkan bahwa pendapatan usaha, beban usaha, dan bagi hasil memiliki pengaruh terhadap laba bersih yang diterima bank.

Penelitian ini berusaha untuk mengungkapkan pengaruh dari pendapatan usaha, beban usaha, dan bagi hasil pihak ketiga terhadap laba usaha. Hal ini menarik untuk diteliti karena adanya perkembangan pendapatan usaha, beban usaha dan laba usaha PT Bank Syariah Mandiri yang tidak proporsional, sehingga mengungkapkan adanya pengaruh dari pendapatan usaha, beban usaha, dan bagi hasil pihak ketiga dalam kondisi bank yang tidak proporsional.

\section{Kajian Literatur}

\section{Pendapatan Usaha Bank Syariah}

Furywardhana

pendapatan usaha Bank Syariah terdiri dari pendapatan murabahah, pendapatan salam, pendapatan ijarah, pendapatan bagi hasil mudharabah, pendapatan bagi hasil musyarakah, pendapatan usaha utama lainnya, pendapatan imbal jasa perbankan, dan pendapatan imbal jasa investasi terikat

Penelitian terdahulu yang dilakukan oleh Pasaribu (2018) menunjukkan secara 
parsial, hasil penelitian ini menunjukkan bahwa pendapatan usaha memiliki pengaruh postif terhadap laba bersih. Sedangkan beban operasional tidak berpengaruh terhadap laba bersih. Sedangkan, secara simultan hasil penelitian ini menunjukkan bahwa variabel pendapatan usaha dan beban operasional secara simultan berpengaruh terhadap laba bersih. Penelitian lainnya yang dilakukan Efilia (2014) menunjukkan bahwa pendapatan usaha berpengaruh signifikan terhadap laba bersih pada perusahaan yang terdaftar di BEI periode 2008-2012. Berdasarkan kedua penelitian tersebut menunjukkan bahwa secara konsisten pendapatan usaha memiliki pengaruh terhadap laba usaha.

\section{Beban Usaha pada Bank Syariah}

Menurut laporan keuangan auditor independen Bank Syariah Mandiri (2015) biaya usaha usaha dikelompokkan menjadi beban kepegawaian, beban administrasia, beban penyisihan kerugian aset produktif, beban penyusutan aset tetap, beban bagi hasil surat berharga, beban bagi hasil surat berharga subordinasi, beban penyisihan kerugian aset tidak produktif, beban penyisihan kerugian komitmen dan kontijensi, beban bonus simpanan wadiah, dan beban usaha lainnya.

Penelitian yang dilakukan Nasution dan Marlina (2013) secara analisis menguraikan beban usaha. Penelitian tersebut menunjukkan bahwa beban administrasi dan umum tidak berpengaruh signifikan terhadap laba bersih. Beban tenaga kerja tidak berpengaruh signifikan terhadap laba bersih. Hal ini menunjukkan bahwa apabila beban bunga naik maka laba bersih akan naik juga, demikian sebaliknya. Sedangkan variabel beban administrasi dan umum serta beban tenaga kerja tidak berpengaruh signifikan terhadap laba bersih.

\section{Bagi Hasil Pihak Ketiga}

Menurut Bank Syariah Mandiri (2018), hak nasabah atas bagi hasil dana syirkah temporer merupakan bagian bagi laba milik nasabah yang didasarkan pada prinsip mudharabah muthlaqah, mudharabah muqayyadah, dan mudharabah musytarakah atas hasil pengelolaan dana mereka oleh bank syariah. Pendapatan yang dibagikan adalah pendapatan yang telah diterima. Pembagian laba dilakukan berdasarkan prinsip bagi hasil yaitu dihitung dari pendapatan bank syariah yang diterima berupa laba bruto (gross profit margin).

Jumlah pendapatan marjin dan bagi hasil atas pembiayaan yang diberikan dan atas aset produktif lainnya akan dibagikan kepada nasabah penyimpan dana dan bank syariah, dihitung secara proporsional sesuai dengan alokasi dana nasabah dan bank syariah yang dipakai dalam pembiayaan yang diberikan dan aset produktif lainnya yang disalurkan. Selanjutnya, jumlah pendapatan marjin dan bagi hasil yang tersedia untuk nasabah tersebut kemudian dibagihasilkan ke nasabah penabung dan deposan sebagai shahibul maal dan bank syariah sebagai mudharib sesuai dengan porsi nisbah bagi hasil yang telah disepakati bersama sebelumnya.

Penelitian yang dilakukan oleh Elvitasari dan Dalimunthe (2019) menunjukkan hasil bahwa fasilitas bank mampu memperkuat pengaruh dana pihak ketiga terhadap laba operasi. Penelitian lainnya yang dilakukan oleh Fitri (2016) menunjukkan hasil bahwa secara teoritis dan empiris dana pihak ketiga (DPK) terbukti memiliki peranan yang strategis terhadap kinerja lembaga pembiayaan syariah yang meliputi aspek kepastian manajemen untuk memberikan pembiayaan/kredit, dan memengaruhi kinerja usaha terutama pada upaya menciptakan laba operasional yang sangat menentukan kelangsungan usaha lembaga pembiayaan syariah. Faktor yang sangat memengaruhi tingkat perkembangan dana 
pihak ketiga dalam isu makro adalah tingkat pendapatan masyarakat hal ini sangat relevan dengan teori dasarnya yaitu bahwa fungsi simpanan sangat dipengaruhi tingkat pendapatan. Begitu juga secara empiris keputusan seseorang akan menabung jika terdapat kelebihan pendapatan.

\section{Kerangka Pemikiran}

Bentuk kerangka pemikiran penelitian ini, penulis sajikan ke dalam Gambar 1.

\section{Gambar 1. Kerangka Pemikiran}

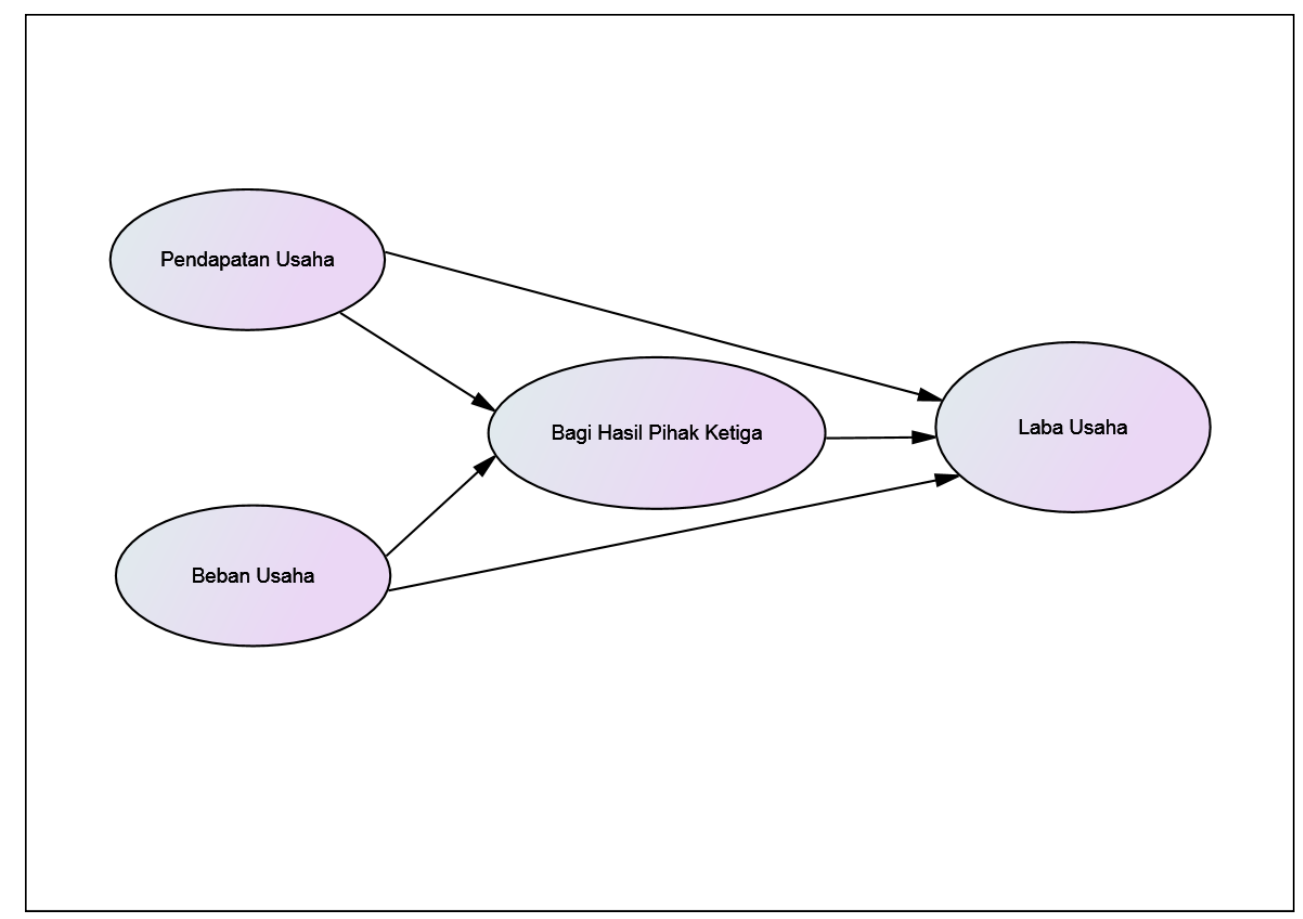

\section{Hipotesis Penelitian}

Dalam melakukan penelitian ini penulis merancang dua hipotesis penelitian diantaranya pertama terdapat pengaruh pendapatan usaha dan beban usaha terhadap bagi hasil pihak ketiga baik secara simultan maupun parsial. Hipotesis kedua terdapat pengaruh pendapatan usaha, beban usaha dan bagi hasil pihak ketiga terhadap laba usaha baik secara simultan maupun parsial.

\section{Metode Penelitian}

Metode penelitian yang digunakan adalah deskriptif dan verifikatif. Penelitian deskriptif adalah penilitan yang bertujuan mendapatkan gambaran tentang ciri-ciri variable penelitian sedangkan sifat penelitian verifikatif pada dasarnya ingin menguji kebenaran suatu hipotesis yang diaksanakan melalui pengumpulan data di lapangan. Dalam penelitian ini akan menguji hubungan pendapatan usaha, beban usaha dan bagi hasil pihak ketiga serta pengaruhnya terhadap laba usaha di Bank Syariah Mandiri.

Tipe penelitian ini adalah kausalitas, yaitu tipe penelitian adanya hubungan sebab akibat antara variable bebas (independent variable) dan variable terikat (depent variable). Jangka waktu dalam penelitian ini adalah time series yaitu data dikumpulkan dari laporan keuangan Bank Syariah Mandiri sejak tahun 2008 sampai 2014 dari website resmi Bank Syariah Mandiri (www.syariahmandiri.com.id).

\section{Sumber dan Cara Penentuan Data}

Penulis dalam penelitian untuk mencari sumber data menggunakan 
sumber data sekunder berupa laporan atau dokumentasi yang tersedia pada website resmi Bank Syariah Mandiri (www.syariahmandiri.com.id) berupa laporan keuangan triwulanan yang telah dipublikasikan (terlampir). Data yang digunakan adalah data triwulanan sejak tahun 2008 sampai $2014(\mathrm{~N}=35)$

\section{Teknik Pengumpulan Data.}

Teknik pengumpulan data yang dilakukan adalah teknik dokumentasi melalui studi kepustakaan, yaitu mempelajari buku-buku atau bahan-bahan tertulis sebagai referensi yang berhubungan dengan penelitian serta mengunduh data laporan keuangan Bank Syariah Mandiri dari website resminya (www.syariahmandiri.co.id)

\section{Metode Analisis dan Uji Hipotesis}

Metode analisis yang digunakan dalam penelitian ini adalah dengan melakukan analisis regresi linear berganda yang dirancang untuk meneliti pengaruh variabel independen terhadap variabel dependen. Metode yang digunakan adalah Ordinary Least Square (OLS) yang dinyatakan dengan angka-angka yang dalam perhitungannya menggunakan metode statistik yang dibantu dengan program pengolah data statistik yakni SPSS.

Metode-metode yang digunakan yaitu analisis deskriptif, uji asumsi klasik, uji signifikansi simultan (uji statitik F), koefisien determinasi R2, dan uji signifikansi parameter individual (uji statistik t). Adapun bentuk persamaan regresi linear berganda yang digunakan dapat dirumuskan :

$$
\mathrm{Y}=\beta 0+\beta 1 \mathrm{X} 1+\beta 2 \mathrm{X} 2+\mathrm{et}
$$

Keterangan :

$$
\begin{aligned}
& Y=\text { Laba Usaha } \\
& \beta 0=\text { Konstanta } \\
& \beta 1, \beta 2=\text { Koefisien regresi } \\
& X 1=\text { Pendapatan Usaha } \\
& X 2=\text { Beban Usaha } \\
& \text { et }=\text { error term }
\end{aligned}
$$

\section{Pengujian Asumsi Klasik Uji Normalitas}

Uji normalitas dalam model regresi bertujuan untuk mengetahui dependen variabel dan independen variabel mempunyai distribusi normal atau tidak.Model regresi yang baik adalah yang memiliki distribusi normal atau mendektai normal.

\section{Uji Multikolonieritas}

Menurut Ghozali (2011:105) uji ini berutujuan menguji apakah pada model regresi ditemukan adanya korelasi antar variabel independen. Pada model regresi yang baik seharusnya antar variabel independen tidak terjadi kolerasi.

\section{Uji Autokolerasi}

Uji autokolerasi bertujuan menguji apakah dalam suatu model regresi linear ada korelasi antara kesalahan penganggu pada periode $t$ dengan kesalahan pada periode t-1. jika terjadi korelasi, maka dinamakan problem autokolerasi. Autokolerasi muncul karena observasi yang berurutan sepanjang waktu berkaitan satu sama lain. Masalah ini timbul karena residual tidak bebas dari satu observasi ke observasi lainnya (Ghozali,2011:110).

\section{Uji Heteroskedastisitas}

Menurut (Ghozali,2011:139) uji Heteroskedastisitas bertujuan menguji apakah dalam model regresi terjadi ketidaksamaan variance dari residual satu ke pengamatan yang lain. Model regresi yang baik adalah yang homoskedastisitas atau tidak terjadi heteroskedastisitas. Salah satu cara untuk mendeteksi ada atau tidaknya heterokedastisitas itu dengan menggunakan uji Park.

\section{Pengujian Hipotesis}

Untuk melakukan pengujian terhadap hipotesis-hipotesis yang diajukan, perlu digunakan analisi regresi melalui uji $t$ maupun uji $F$. Tujuan digunakan analisis regresi adalah untuk mengetahui pengaruh variabel-variabel independen terhadap variabel dependen, baik secara maupun secara simultan, serta 
mengetahui besarnya dominasi variabelvariabel independen terhadap variabel dependen. Metode pengujian terhadap hipotesa yang diajukan dilakukan dengan pengujian secara parsial dan pengujian secara simultan.
Hasil dan Pembahasan

Hubungan Pendapatan Usaha dengan Bagi Hasil Pihak Ketiga

Hubungan antara pendapatan usaha dan bagi hasil pihak ketiga seperti terlihat pada Tabel 3 .

Tabel 3. Hubungan Pendapatan Usaha, Beban Usaha, dan Bagi Hasil Pihak Ketiga

\begin{tabular}{|c|c|c|c|c|}
\hline \multicolumn{5}{|c|}{ Correlations } \\
\hline & & $\begin{array}{l}\text { Pendapatan } \\
\text { Usaha }\end{array}$ & $\begin{array}{l}\text { Beban } \\
\text { Usaha }\end{array}$ & $\begin{array}{l}\text { Bagi } \\
\text { Hasil PK }\end{array}$ \\
\hline \multirow{3}{*}{$\begin{array}{l}\text { Pendapa } \\
\text { tan } \\
\text { Usaha }\end{array}$} & Pearson Correlation & 1 & $.930^{* * *}$ & $.966^{* *}$ \\
\hline & Sig. (2-tailed) & & .000 & .000 \\
\hline & $\mathrm{N}$ & 28 & 28 & 28 \\
\hline \multirow{3}{*}{$\begin{array}{l}\text { Beban } \\
\text { Usaha }\end{array}$} & Pearson Correlation & $.930^{* * *}$ & 1 & $.900^{* *}$ \\
\hline & Sig. (2-tailed) & .000 & & .000 \\
\hline & $\mathrm{N}$ & 28 & 28 & 28 \\
\hline \multirow{3}{*}{$\begin{array}{l}\text { Bagi } \\
\text { Hasil } \\
\text { PK }\end{array}$} & Pearson Correlation & $.966^{* *}$ & $.900^{* *}$ & 1 \\
\hline & Sig. (2-tailed) & .000 & .000 & \\
\hline & $\mathrm{N}$ & 28 & 28 & 28 \\
\hline
\end{tabular}

Korelasi antara pendapatan usaha dengan bagi hasil pihak ketiga menunjukkan nilai signifikansi 0,000 , lebih kecil dari 0,05 berarti menunjukkan korelasi yang signifikan dengan derajat korelasi $0,966^{* *}$, menunjukkan hubungan positif yang sangat kuat.

\section{Hubungan Beban Usaha dengan Bagi Hasil Pihak Ketiga}

Hubungan antara beban usaha dan bagi hasil pihak ketiga seperti terlihat pada Tabel 3. Dari Tabel 3 tersebut dapat diketahui bahwa korelasi antara beban usaha dengan bagi hasil pihak ketiga menunjukkan nilai signifikansi 0,000 , lebih kecil dari 0,05 berarti menunjukkan korelasi yang signifikan dengan derajat korelasi $0,900^{* *}$, menunjukkan hubungan positif yang sangat kuat.

\section{Pengaruh Bagi Hasil Pihak Ketiga Terhadap Laba Usaha Uji $R$ untuk nilai regresi}

Hasil output dari pengolahan data bagi hasil pihak ketiga dengan laba usaha menunjukkan tabel model summary sebagai berikut :

Tabel 4. Pengaruh Bagi Hasil Pihak Ketiga terhadap Laba Usaha

\begin{tabular}{|l|c|r|c|r|}
\hline \multicolumn{5}{|c|}{ Model Summary } \\
\hline Model & $\mathrm{R}$ & $\begin{array}{c}\mathrm{R} \\
\text { Square }\end{array}$ & $\begin{array}{c}\text { Adjusted R } \\
\text { Square }\end{array}$ & Std. Error of the Estimate \\
\hline 1 & $.140^{\mathrm{a}}$ & .019 & -.018 & 131983.939 \\
\hline \multicolumn{2}{|l|}{ a. Predictors: (Constant), Bagi Hasil PK } \\
\hline
\end{tabular}

Dari Tabel 4, dapat diketahui bahwa nilai korelasi (R) antara bagi hasil pihak ketiga dengan laba usaha adalah 0,140 . Sedangkan nilai koefisien determinasi yang ditunjukkan dengan notasi R Square $\left(\mathrm{R}^{2}\right)$ menunjukkan nilai 0,019 yang berarti pengaruh bagi hasil pihak ketiga terhadap laba usaha pada Bank Syariah Mandiri 
hanya $1,9 \%$, sedangkan pengaruh sisanya $98,1 \%$ dipengaruhi oleh faktor lain.

Uji F
Hasil output dari pengolahan data bagi hasil pihak ketiga dengan laba usaha menunjukkan tabel ANOVA yang dapat dilihat pada Tabel 5

Tabel 5. Uji F Pengaruh Bagi Hasil Pihak Ketiga terhadap Laba Usaha

\begin{tabular}{|l|l|r|r|r|l|l|}
\hline \multicolumn{7}{|c|}{ ANOVA $^{\mathrm{a}}$} \\
\hline \multicolumn{2}{|l|}{ Model } & Sum of Squares & Df & Mean Square & F & Sig. \\
\hline \multirow{3}{*}{1} & Regression & 9005806078.843 & 1 & 9005806078.843 & .517 & $.479^{\mathrm{b}}$ \\
\cline { 2 - 7 } & Residual & 452913766748.122 & 26 & 17419760259.543 & & \\
\cline { 2 - 7 } & Total & 461919572826.964 & 27 & & & \\
\hline \multicolumn{2}{|l|}{ a. Dependent Variable: Laba Usaha } \\
\hline \multicolumn{2}{|l}{ b. Predictors: (Constant), Bagi Hasil PK } \\
\hline
\end{tabular}

Dari Tabel 5 dapat diketahui bahwa $\mathrm{F}$ hitung $=0,517$ dengan tingkat signifikansi/probabilitas 0,479 lebih besar dari 0,05 maka model regresi tidak dapat digunakan untuk memprediksi variabel laba usaha.

Dari Tabel 5 juga dapat diketahui bahwa nilai $\mathrm{F}$ hitung $=0,517$ dan nilai $\mathrm{F}$ tabel dapat dicari dengan cara sebagai berikut :

$\mathrm{F}$ tabel $=(\mathrm{df}$ penyebut $; \mathrm{df}$ pembilang)

$\mathrm{F}$ tabel $=(\mathrm{N}-\mathrm{k}-1 ; \mathrm{k})$

$\mathrm{F}$ tabel $=(26 ; 1)$
F tabel $=4,23$

Dari hasil olahan data pada Tabel 5 diketahui bahwa F hitung $0,517<\mathrm{F}$ tabel 4,23 maka Ho diterima dan Ha ditolak yang berarti tidak ada pengaruh yang signifikan antara bagi hasil pihak ketiga dengan laba usaha.

Uji t

Hasil output dari pengolahan data bagi hasil pihak ketiga dan laba usaha menunjukkan tabel coefficients yang dapat dilihat pada Tabel 6 .

Tabel 6. Koefisien Bagi Hasil Pihak Ketiga terhadap Laba Usaha

\begin{tabular}{|c|c|c|c|c|c|c|}
\hline \multicolumn{7}{|c|}{ Coefficients $^{\mathrm{a}}$} \\
\hline \multirow{2}{*}{\multicolumn{2}{|c|}{ Model }} & \multicolumn{2}{|c|}{$\begin{array}{l}\text { Unstandardized } \\
\text { Coefficients }\end{array}$} & \multirow{2}{*}{$\begin{array}{l}\text { Standardized } \\
\text { Coefficients } \\
\text { Beta }\end{array}$} & \multirow[t]{2}{*}{$\mathrm{T}$} & \multirow[t]{2}{*}{ Sig. } \\
\hline & & $\mathrm{B}$ & Std. Error & & & \\
\hline \multirow[t]{2}{*}{1} & (Constant) & 94144.443 & 69608.774 & & 1.352 & 0.19 \\
\hline & $\begin{array}{l}\text { Bagi Hasil } \\
\text { PK }\end{array}$ & 0.116 & 0.161 & 0.14 & 0.719 & 0.48 \\
\hline
\end{tabular}

Dari data pada Tabel 6 dapat diketahui bahwa $\mathrm{t}$ hitung menunjukkan

$\mathrm{T}$ tabel $=(\alpha / 2 ; \mathrm{n}-\mathrm{k}-1)$

$\mathrm{T}$ tabel $=(0,05 / 2 ; 28-1-1)$

$\mathrm{T}$ tabel $=(0,025 ; 26)$

$\mathrm{T}$ tabel $=2,05553$

Karena t hitung 0,719 < t tabel 2,05553 maka Ho diterima dan Ha ditolak yang nilai 0,719 sedangkan $\mathrm{t}$ tabel dapat dihitung dengan cara :

berarti tidak terdapat pengaruh yang signifikan antara bagi hasil pihak ketiga dengan laba usaha.

Dari Tabel 6 dapat diketahui nilai konstanta (a) adalah 94.144,443 dan nilai 
b adalah 0,116. Sehingga persamaan regresinya dapat ditulis sebagai berikut:

$$
\mathrm{Y}=\mathrm{a}+\mathrm{bX}
$$

Laba Usaha $=94 \cdot 144,443+(0,116 \mathrm{x}$

Bagi Hasil Pihak Ketiga)

\section{Pengaruh Pendapatan Usaha \\ Terhadap Laba Usaha \\ Uji R untuk nilai regresi}

Output dari pengolahan data pendapatan usaha dan laba usaha menunjukkan tabel model summary yang dapat dilihat pada Tabel 7 .

Tabel 7. Pengaruh Pendapatan Usaha terhadap Laba Usaha

\begin{tabular}{|l|l|l|l|l|}
\hline \multicolumn{5}{|c|}{ Model Summary } \\
\hline Model & $\mathrm{R}$ & R Square & $\begin{array}{l}\text { Adjusted R } \\
\text { Square }\end{array}$ & $\begin{array}{l}\text { Std. Error of the } \\
\text { Estimate }\end{array}$ \\
\hline 1 & $.234^{\mathrm{a}}$ & .055 & .019 & 129577.176 \\
\hline a. Predictors: (Constant), Pendapatan Usaha \\
\hline
\end{tabular}

Dari Tabel 7, dapat diketahui bahwa nilai korelasi (R) antara pendapatan usaha dengan laba usaha adalah 0,234. Sedangkan nilai koefisien determinasi yang ditunjukkan dengan notasi $\mathrm{R}$ Square $\left(R^{2}\right)$ menunjukkan nilai 0,055 yang berarti pengaruh pendapatan usaha terhadap laba usaha pada Bank Syariah Mandiri hanya
$5,5 \%$, sedangkan pengaruh sisanya $94,5 \%$ dipengaruhi oleh faktor lain.

\section{Uji F}

Hasil output dari pengolahan data pendapatan usaha dan laba usaha menunjukkan tabel ANOVA yang dapat dilihat pada Tabel 8 .

\section{Tabel 8. Uji F Pengaruh Pendapatan Usaha terhadap Laba Usaha}

\begin{tabular}{|l|l|c|r|c|c|c|}
\hline \multicolumn{7}{|c|}{ ANOVA $^{\mathrm{a}}$} \\
\hline \multicolumn{2}{|c|}{ Model } & Sum of Squares & Df & Mean Square & F & Sig. \\
\hline \multirow{2}{*}{1} & Regression & 25373211506.698 & 1 & 25373211506.698 & 1.511 & $.230^{\mathrm{b}}$ \\
\cline { 2 - 7 } & Residual & 436546361320.266 & 26 & 16790244666.164 & & \\
\cline { 2 - 7 } & Total & 461919572826.964 & 27 & & & \\
\hline \\
a. Dependent Variable: Laba Usaha \\
b. Predictors: (Constant), Pendapatan Usaha \\
\hline
\end{tabular}

Dari Tabel 8 dapat diketahui bahwa $\mathrm{F}$ hitung $=1,511$ dengan tingkat signifikansi/probabilitas 0,230 lebih besar dari 0,05 maka model regresi tidak dapat digunakan untuk memprediksi variabel laba usaha.

$$
\begin{aligned}
& \mathrm{F} \text { tabel }=(\mathrm{N}-\mathrm{k}-1 ; \mathrm{k}) \\
& \mathrm{F} \text { tabel }=(26 ; 1) \\
& \mathrm{F} \text { tabel }=4,23
\end{aligned}
$$

Dari hasil olahan data tersebut diketahui bahwa F hitung 0,511 < F tabel 4,23 maka Ho diterima dan Ha ditolak yang berarti tidak ada pengaruh yang signifikan antara pendapatan usaha dengan laba usaha.
Dari Tabel 8 juga dapat diketahui bahwa nilai $\mathrm{F}$ hitung $=0,511$ dan nilai $\mathrm{F}$ tabel dapat dicari dengan cara sebagai berikut :

$\mathrm{F}$ tabel $=(\mathrm{df}$ penyebut ; $\mathrm{df}$ pembilang)

Uji t

Hasil output dari pengolahan data pendapatan usaha dan laba usaha menunjukkan tabel coefficients sebagai berikut : 
Tabel 9. Koefisien Pengaruh Pendapatan Usaha terhadap Laba Usaha

\begin{tabular}{|c|c|c|c|c|c|c|}
\hline \multicolumn{7}{|c|}{ Coefficients $^{\mathrm{a}}$} \\
\hline \multirow{2}{*}{\multicolumn{2}{|c|}{ Model }} & \multicolumn{2}{|c|}{$\begin{array}{l}\text { Unstandardized } \\
\text { Coefficients }\end{array}$} & \multirow{2}{*}{$\begin{array}{c}\text { Standardized } \\
\text { Coefficients } \\
\text { Beta }\end{array}$} & \multirow[t]{2}{*}{$\mathrm{T}$} & \multirow[t]{2}{*}{ Sig. } \\
\hline & & $\mathrm{B}$ & Std. Error & & & \\
\hline \multirow[t]{2}{*}{1} & (Constant) & 67025.521 & 64870.41 & & 1.03 & 0.31 \\
\hline & $\begin{array}{l}\text { Pendapatan } \\
\text { Usaha }\end{array}$ & 0.063 & 0.051 & 0.234 & 1.23 & 0.23 \\
\hline
\end{tabular}

Dari data pada Tabel 9 diketahui bahwa t hitung menunjukkan nilai 1,23 sedangkan t tabel dapat dihitung dengan cara :

$$
\begin{aligned}
\mathrm{T} \text { tabel } & =(\alpha / 2 ; \mathrm{n}-\mathrm{k}-1) \\
\mathrm{T} \text { tabel } & =(0,05 / 2 ; 28-1-1) \\
\mathrm{T} \text { tabel } & =(0,025 ; 26) \\
\mathrm{T} \text { tabel } & =2,05553
\end{aligned}
$$

Karena $\mathrm{t}$ hitung $1,23<\mathrm{t}$ tabel 2, 05553 maka Ho diterima dan Ha ditolak yang berarti tidak terdapat pengaruh yang signifikan antara pendapatan usaha dengan laba usaha.
Dari Tabel 9 dapat diketahui nilai konstanta (a) adalah 67.025,521 dan nilai b adalah 0,063. Sehingga persamaan regresinya dapat ditulis sebagai berikut:

$$
\mathrm{Y}=\mathrm{a}+\mathrm{bX}
$$

Laba Usaha $=67.025,521+(0,063 x$ Pendapatan Usaha)

\section{Pengaruh Beban Usaha Terhadap \\ Laba Usaha \\ Uji R untuk nilai regresi}

Output dari pengolahan data beban usaha dan laba usaha menunjukkan tabel model summary sebagai berikut :

Tabel 10. Pengaruh Beban Usaha terhadap Laba Usaha

\begin{tabular}{|l|l|l|l|r|}
\hline \multicolumn{5}{|c|}{ Model Summary } \\
\hline Model & R & R Square & Adjusted R Square & Std. Error of the Estimate \\
\hline 1 & $.120^{\mathrm{a}}$ & .014 & -.024 & 132333.332 \\
\hline a. Predictors: (Constant), Beban Usaha \\
\hline
\end{tabular}

Dari Tabel 10 dapat diketahui bahwa nilai korelasi $(\mathrm{R})$ antara beban usaha dengan laba usaha adalah 0,120 . Sedangkan nilai koefisien determinasi yang ditunjukkan dengan notasi $\mathrm{R}$ Square $\left(R^{2}\right)$ menunjukkan nilai 0,014 yang berarti pengaruh beban usaha terhadap laba usaha pada Bank Syariah Mandiri hanya
$1,4 \%$, sedangkan pengaruh sisanya 98,6\% dipengaruhi oleh faktor lain.

Uji F

\begin{tabular}{|c|c|c|c|c|c|c|}
\hline \multicolumn{7}{|c|}{ ANOVA $^{a}$} \\
\hline \multicolumn{2}{|c|}{ Model } & Sum of Squares & Df & Mean Square & $\mathrm{F}$ & Sig. \\
\hline \multirow[t]{3}{*}{1} & Regression & 6604689994.147 & 1 & 6604689994.147 & .377 & $.544^{\mathrm{b}}$ \\
\hline & Residual & 455314882832.817 & 26 & 17512110878.185 & & \\
\hline & Total & 461919572826.964 & 27 & & & \\
\hline \multicolumn{7}{|c|}{ a. Dependent Variable: Laba Usaha } \\
\hline & redictors. $(C$ & nstant), Beban Usaha & & & & \\
\hline
\end{tabular}

Hasil output dari pengolahan data beban usaha dan laba usaha menunjukkan tabel ANOVA sebagai berikut :

Tabel 11. Uji F Pengaruh Beban Usaha terhadap Laba Usaha 
Dari Tabel 11 dapat diketahui bahwa $\mathrm{F}$ hitung $=0,377$ dengan tingkat signifikansi/probabilitas 0,544 lebih besar dari 0,05 maka model regresi tidak dapat digunakan untuk memprediksi variabel laba usaha.

Dari tabel Tabel 11 juga dapat diketahui bahwa nilai $\mathrm{F}$ hitung $=0,377$ dan nilai $F$ tabel dapat dicari dengan cara sebagai berikut :

$\mathrm{F}$ tabel $=(\mathrm{N}-\mathrm{k}-1 ; \mathrm{k})$
$\mathrm{F}$ tabel $=(\mathrm{df}$ penyebut $; \mathrm{df}$

$$
\begin{aligned}
& \mathrm{F} \text { tabel }=(26 ; 1) \\
& \mathrm{F} \text { tabel }=4,23
\end{aligned}
$$

Dari hasil olahan data di atas diketahui bahwa $\mathrm{F}$ hitung $0,377<\mathrm{F}$ tabel 4,23 maka Ho diterima dan Ha ditolak yang berarti tidak ada pengaruh yang signifikan antara beban usaha terhadap laba usaha.

\section{Uji t}

Hasil output dari pengolahan data beban usaha dan laba usaha menunjukkan tabel coefficients sebagai berikut :

Tabel 12. Koefisien Pengaruh Beban Usaha terhadap Laba Usaha

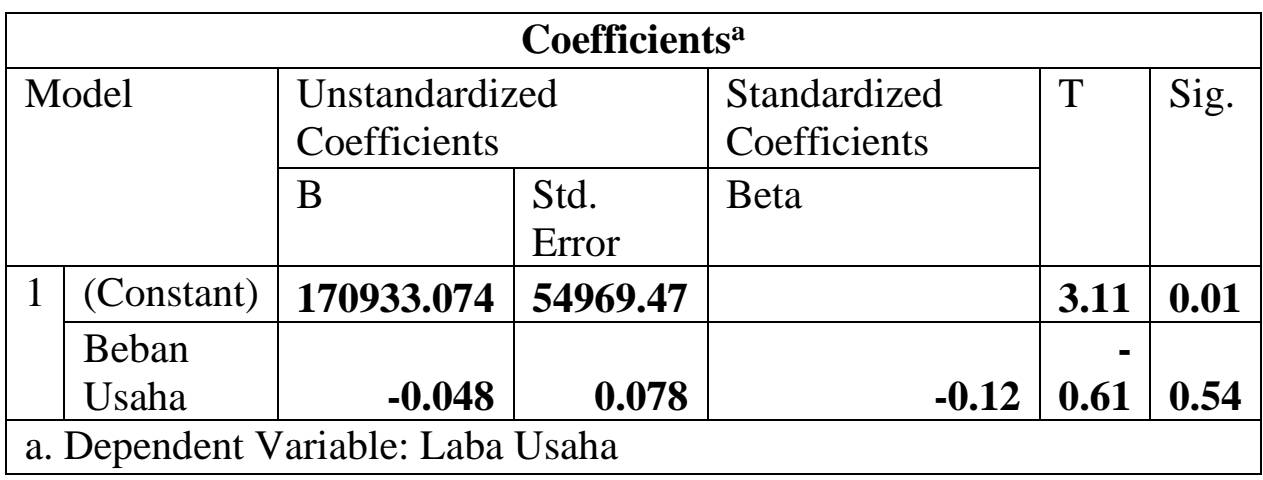

Dari data pada Tabel 12 diketahui bahwa t hitung menunjukkan nilai 0,61 sedangkan $t$ tabel dapat dihitung dengan cara :

$$
\begin{aligned}
& \text { T tabel }=(\alpha / 2 ; \mathrm{n}-\mathrm{k}-1) \\
& \mathrm{T} \text { tabel }=(0,05 / 2 ; 28-1-1) \\
& \mathrm{T} \text { tabel }=(0,025 ; 26) \\
& \mathrm{T} \text { tabel }=2,05553
\end{aligned}
$$

Karena t hitung 0,61 $<\mathrm{t}$ tabel 2 , 05553 maka Ho diterima dan Ha ditolak yang berarti tidak terdapat pengaruh yang signifikan antara beban usaha dengan laba usaha.

Dari tabel di atas juga dapat diketahui nilai konstanta (a) adalah
170.933,074 dan nilai b adalah $-0,048$. Sehingga persamaan regresinya dapat ditulis sebagai berikut:

$$
\mathrm{Y}=\mathrm{a}+\mathrm{bX}
$$

Laba Usaha $=170.933,074+(-0,048$

x Beban Usaha)

\section{Pengaruh Pendapatan Usaha dan Beban Usaha Terhadap Laba Usaha Uji $R$ untuk nilai regresi}

Hasil output dari pengolahan data pendapatan usaha, beban usaha dan laba usaha menunjukkan tabel model summary sebagai berikut :

Tabel 13. Pengaruh Pendapatan Usaha dan Beban Usaha terhadap Laba Usaha

\begin{tabular}{|l|r|r|r|r|}
\hline \multicolumn{5}{|c|}{ Model Summary } \\
\hline Model & $\mathrm{R}$ & R Square & Adjusted R Square & $\begin{array}{c}\text { Std. Error of the } \\
\text { Estimate }\end{array}$ \\
\hline 1 & $.949^{\mathrm{a}}$ & .901 & .893 & 42732.482 \\
\hline a. Predictors: (Constant), Beban Usaha, Pendapatan Usaha \\
\hline
\end{tabular}


Dari Tabel 13 dapat diketahui bahwa nilai korelasi $(\mathrm{R})$ antara pendapatan usaha dan beban usaha terhadap laba usaha adalah 0,949 . Sedangkan nilai koefisien determinasi yang ditunjukkan dengan notasi $\mathrm{R}$ Square $\left(\mathrm{R}^{2}\right)$ menunjukkan nilai 0,901 yang berarti pengaruh pendapatan usaha dan beban usaha $t$ terhadap laba usaha pada Bank Syariah Mandiri hanya
$90,1 \%$, sedangkan pengaruh sisanya 9,1\% dipengaruhi oleh faktor lain.

\section{Uji F}

Hasil output dari pengolahan data pendapatan usaha, beban usaha dan laba usaha menunjukkan tabel ANOVA sebagai berikut :

\section{Tabel 14. Uji F Pengaruh Pendapatan Usaha dan Beban Usaha terhadap Laba Usaha}

\begin{tabular}{|l|l|r|r|r|c|c|}
\hline \multicolumn{7}{|c|}{ ANOVA $^{\mathrm{a}}$} \\
\hline \multicolumn{2}{|c|}{ Model } & \multicolumn{1}{c|}{ Sum of Squares } & Df & Mean Square & F & Sig. \\
\hline \multirow{2}{*}{1} & Regression & 416267947507.208 & 2 & 208133973753.604 & 113.979 & $.000^{\mathrm{b}}$ \\
\cline { 2 - 7 } & Residual & 45651625319.756 & 25 & 1826065012.790 & & \\
\cline { 2 - 7 } & Total & 461919572826.964 & 27 & & & \\
\hline
\end{tabular}

Dari Tabel 14 dapat diketahui bahwa $\mathrm{F}$ hitung $=113,979$ dengan tingkat signifikansi/probabilitas 0,000 lebih kecil dari 0,05 maka model regresi dapat digunakan untuk memprediksi variabel laba usaha.

Dari Tabel 14 juga dapat diketahui bahwa nilai $\mathrm{F}$ hitung $=113,979$ dan nilai $\mathrm{F}$ tabel dapat dicari dengan cara sebagai berikut :

$\mathrm{F}$ tabel $=(\mathrm{df}$ penyebut $; \mathrm{df}$ pembilang)

$\mathrm{F}$ tabel $=(\mathrm{N}-\mathrm{k}-1 ; \mathrm{k})$

$$
\begin{aligned}
& \mathrm{F} \text { tabel }=(25 ; 2) \\
& \mathrm{F} \text { tabel }=3,39
\end{aligned}
$$

Dari hasil olahan data di atas diketahui bahwa $\mathrm{F}$ hitung 113,979 > F tabel 4,23 maka Ho ditolak dan Ha diterima yang berarti tidak ada pengaruh yang signifikan antara bagi hasil pihak ketiga dengan laba usaha.

Uji $\mathbf{t}$

Hasil output dari pengolahan data beban usaha dan laba usaha menunjukkan tabel coefficients sebagai berikut :

Tabel 15. Koefisin Pengaruh Pendapatan Usaha dan Beban Usaha terhadap Laba

\begin{tabular}{|c|c|c|c|c|c|c|}
\hline \multicolumn{7}{|c|}{ Coefficients $^{\mathrm{a}}$} \\
\hline \multirow{2}{*}{\multicolumn{2}{|c|}{ Model }} & \multicolumn{2}{|c|}{ Unstandardized Coefficients } & \multirow{2}{*}{$\begin{array}{l}\text { Standardized } \\
\text { Coefficients } \\
\text { Beta }\end{array}$} & \multirow[t]{2}{*}{$\mathrm{T}$} & \multirow[t]{2}{*}{ Sig. } \\
\hline & & B & Std. Error & & & \\
\hline \multirow[t]{3}{*}{1} & (Constant) & -37473.577 & 22554.01 & & -1.66 & 0.11 \\
\hline & $\begin{array}{l}\text { Pendapatan } \\
\text { Usaha }\end{array}$ & 0.691 & 0.046 & 2.566 & 15 & 0 \\
\hline & $\begin{array}{l}\text { Beban } \\
\text { Usaha }\end{array}$ & -1.007 & 0.069 & -2.507 & -14.6 & 0 \\
\hline
\end{tabular}
Usaha

Dari data pada Tabel 15 diketahui bahwa thitung pendapatan usaha terhadap 
laba usaha menunjukkan nilai 15 sedangkan $t$ tabel dapat dihitung dengan cara :

$$
\begin{aligned}
\mathrm{T} \text { tabel } & =(\alpha / 2 ; \mathrm{n}-\mathrm{k}-1) \\
\mathrm{T} \text { tabel } & =(0,05 / 2 ; 28-2-1) \\
\mathrm{T} \text { tabel } & =(0,025 ; 25) \\
\mathrm{T} \text { tabel } & =2,05954
\end{aligned}
$$

Karena t hitung $15>\mathrm{t}$ tabel 2, 05553 maka Ho ditolak dan Ha diterima yang berarti terdapat pengaruh yang signifikan antara pendapatan usaha dengan laba usaha.

Dari data Tabel 15 juga diketahui bahwa thitung beban usaha terhadap laba usaha menunjukkan nilai -14,6 sedangkan $\mathrm{t}$ tabel dapat dihitung dengan cara :

$$
\begin{aligned}
& \mathrm{T} \text { tabel }=(\alpha / 2 ; \mathrm{n}-\mathrm{k}-1) \\
& \mathrm{T} \text { tabel }=(0,05 / 2 ; 28-2-1) \\
& \mathrm{T} \text { tabel }=(0,025 ; 25) \\
& \mathrm{T} \text { tabel }=2,05954
\end{aligned}
$$

Karena t hitung -14,6 > t tabel 2, 05553 maka Ho ditolak dan Ha diterima yang berarti terdapat pengaruh yang signifikan antara beban usaha dengan laba usaha.

Dari Tabel 15 tersebut dapat diketahui nilai konstanta (a) adalah 3747,577 dan nilai b1 adalah 0,691 dan b2 adalah -1,007. Sehingga persamaan regresinya dapat ditulis sebagai berikut:

$$
\mathrm{Y}=\mathrm{a}+\mathrm{b} 1 \mathrm{X} 1+\mathrm{b} 2 \mathrm{X} 2
$$

Laba Usaha $=-37473,577+(0,691 x$ Pendapatan Usaha $)+(-1,007 \times$ Beban Usaha)

\section{Pengaruh Komponen Pendapatan Usaha Terhadap Laba Usaha}

Komponen pendapatan usaha yang paling memengaruhi laba usaha. Hasil output pengolahan data di SPSS versi 20 ini dapat dilihat sebagaimana tabel berikut:

Tabel 16. Pengaruh Komponen Pendapatan Usaha terhadap Laba Usaha

\begin{tabular}{llcc}
\hline No & Komponen Pendapatan & $\mathbf{R}$ & $\mathbf{R}^{\mathbf{2}}$ \\
\hline 1 & Murabahah & 0.194 & 0,037 \\
\hline 2 & Istishna & 0,111 & 0,012 \\
\hline 3 & Ijaroh & 0,246 & 0,061 \\
\hline 4 & Mudharabah & 0,651 & 0,424 \\
\hline 5 & Musyarakah & 0,194 & 0,038 \\
\hline 6 & Jasa lainnya & 0,265 & 0,070 \\
\hline 7 & Imbal Jasa Bank & 0,306 & 0,094 \\
\hline 8 & Imbal Jasa Investasi & 0,421 & 0,177 \\
\hline
\end{tabular}

Dari Tabel 16 diketahui bahwa yang paling memengaruhi laba usaha adalah pendapatan mudharabah yakni sebesar 0,651 atau memberikan pengaruh terhadap laba usaha sebesar $42,40 \%$. Sedangkan pendapatan yang pengaruhnya terhadap laba adalah pendapatan istishna yakni sebesar 0,111 atau hanya memberikan pengaruh terhadap laba sebesar $1,20 \%$.

\section{Pengaruh Komponen Beban Usaha} Terhadap Laba Usaha

Komponen beban usaha yang paling memengaruhi laba usaha. Hasil output pengolahan data di SPSS versi 20 ini dapat dilihat sebagaimana tabel berikut:

Tabel 17. Pengaruh Komponen Beban Usaha terhadap Laba Usaha

\begin{tabular}{clcc}
\hline No & Komponen Beban Usaha & $\mathbf{R}$ & $\mathbf{R}^{\mathbf{2}}$ \\
\hline 1 & Kepegawaian & 0,134 & 0,020 \\
\hline 2 & Administrasi & 0,017 & 0,000 \\
\hline
\end{tabular}




\begin{tabular}{clcc}
\hline 3 & $\begin{array}{l}\text { Kerugian Penghapusat Aset } \\
\text { Produktif }\end{array}$ & 0,574 & 0,333 \\
\hline 4 & Penyusutan Aset Tetap & 0,120 & 0,015 \\
\hline 5 & Bagi hasil surat berharga & 0,372 & 0,107 \\
\hline 6 & $\begin{array}{l}\text { Bagi hasil surat berhaga } \\
\text { Subordinasi }\end{array}$ & 0,221 & 0,049 \\
\hline 7 & Kerugian komitmen dan kontijensi & 0,186 & 0,035 \\
\hline 8 & Kerugian Aset non Produktif & 0,276 & 0,076 \\
\hline 9 & Bonus titipan wadiah & 0,089 & 0,008 \\
\hline 10 & Beban lain-lain & 0,187 & 0,035 \\
\hline
\end{tabular}

Dari Tabel 17 dapat diketahui bahwa yang paling memengaruhi laba usaha adalah beban kerugian penghapusan aset produktif sebesar 0,574 atau memberikan pengaruh terhadap laba sebesar 33,30\%. Sedangkan beban usaha yang memberikan pengaruh paling kecil terhadap laba usaha adalah beban administrasi yakni sebesar dilakukan di PT. Bank Syariah Mandiri melemahkan penelitian sebelumnya bahwa pendapatan usaha memiliki pengaruh positif yaitu jika terdapat kenaikan jumlah pendapatan usaha, maka laba yang diperoleh oleh Bank juga akan mengalami peningkatan.

Variabel penelitian mengenai beban usaha dalam penelitian ini menunjukkan tidak adanya signifikansi terhadap laba perusahaan, hal ini pula menegaskan penelitian sebelumnya yang dilakukan Nasution dan Marliana yang menyatakan bahwa tidak ada pengaruh beban usaha terhadap laba usaha di Bank. Kondisi ini menandakan bahwa komponen beban perusahaan yang memiliki dana besar tidak berdampak pada perolehan laba perusahaan.

Terkait dengan penelitian Fitri (2016) yang menyatakan bahwa pihak ketiga memiliki peran strategis dalam Bank, berdasarkan penelitian ini pihak ketiga tidak memiliki pengaruh terhadap laba perusahaan. Akan tetapi pada penelitian sebelumnya yang dilakukan Elvitasari dan Dalimunthe (2019) menunjukkan bahwa pengaruh fasilitas mampu mendorong pihak ketiga untuk berpartisipasi meningkatkan laba Bank. Hal tersebut dapat disimpulkan bahwa
0,017 atau memberikan pengaruh terhadap laba usaha hanya sebesar $0,00 \%$.

Hasil penelitian yang diperoleh menunjukkan bahwa tidak konsisten pendapatan usaha berpengaruh yang positif terhadap laba usaha, hal ini menunjukkan bahwa penelitian yang

walaupun fasilitas memiliki pengaruh terhadap pihak ketiga untuk berpartisipasi dalam Bank, hal itu tidak serta merta berpengaruh terhadap laba Bank.

\section{Kesimpulan}

Pengaruh pendapatan usaha terhadap laba usaha tidak secara konsisten menunjukkan adanya pengaruh baik dari penelitian ini maupun penelitian sebelumnya. Hal ini menandakan bahwa pendapatan usaha tidak secara konsisten memiliki pengaruh terhadap laba usaha. Akan tetapi pengaruh dari beban usaha terhadap laba usaha menunjukkan hasil yang konsisten, dimana penelitian terdahulu dan sekarang menunjukkan hasil bahwa beban usaha tidak memiliki pengaruh signifikan terhadap laba usaha. Terdapat hasil mengenai pihak ketiga tidak memiliki pengaruh terhadap laba usaha, hal ini melengkapi penelitian sebelumnya bahwa fasilitas berpengaruh terhadap keterlibatan pihak ketiga, akan tetapi keterlibatan pihak ketiga tersebut tidak memiliki pengaruh terhadap laba usaha. 


\section{Daftar Pustaka}

Bank Syariah Mandiri. (2015). Laporan Biaya Keuangan. Diakses dari https://www.syariahmandiri.co.id/as sets/pdf/laporan-audit/AR-BSM2015-Lap-Keuangan.pdf

Bank Syariah Mandiri. (2018). Laporan Keuangan. Diakses dari https://www.syariahmandiri.co.id/as sets/pdf/laporan-

audit/AR_2018_Mandiri_Syariah_L ap_Audit.pdf

Efilia, M. (2014). Pengaruh Pendapatan Usaha dan Beban Operasional terhadap Laba Bersih pada Perusahaan Kimia dan Keramik, Porselin \& Kaca yang Terdaftar di Bursa Efek Indonesia Periode 20082012. Tugas Akhir. Universitas Maritim Raja Ali Haji. Diakses dari http://jurnal.umrah.ac.id/wpcontent/uploads/gravity forms/1ec61c9cb232a03a96d0947c6478e52 5e/2014/08/JURNAL-MEIZAEFILIA.pdf

Elvitasari, D. \& Dalimunthe, I. P. (2019). Pengaruh Dana Pihak Ketiga terhadap Laba Operasi dengan Fasilitas Bank. Jurnal Renaissance, 4(1), 514-522. Diakses dari http://www.ejournalacademia.org/index.php/renaissance /article/view/94/61

Fitri, M. (2016). Peran Dana Pihak Ketiga dalam Kinerja Lembaga Pembiayaan Syariah dan FaktorFaktor yang Memengaruhinya. Jurnal Economica: Jurnal Ekonomi Islam, 7(1), 73-95. doi: http://dx.doi.org/10.21580/economi ca.2016.7.1.1033

Furywardhana, F. (2009). Akuntansi Syariah. Yogyakarta: Penerbit PPPS.

Ghozali, I. (2011). Aplikasi Analisis Multivariate Dengan Program
SPSS. Semarang: Badan Penerbit Universitas Diponegoro.

Indonesia. (1992). Undang-Undang Republik Indonesia Nomor 7 Tahun 1992 Tentang Perbankan.

Indonesia. (1998). Undang-Undang Republik Indonesia Nomor 10 Tahun 1998 Tentang Perubahan Atas Undang-Undang Nomor 7 Tahun 1992 Tentang Perbankan.

Indonesia. (2008). Undang-Undang Republik Indonesia Nomor 21 Tahun 2008 Tentang Perbankan Syariah.

Laporan Keuangan Bank Syariah Mandiri tahun 2008-2014. Diakses dari www.syariahmandiri.co.id

Nasution, F. R. \& Marliana, L. (2013). Pengaruh Biaya Operasional terhadap Laba Bersih pada Bank Swasta Nasional yang Terdaftar di Bursa Efek Indonesia Periode 20092011. Jurnal Media Informasi Manajemen, 1(3), 1-11. Diakses dari https://jurnal.usu.ac.id/index.php/jm $\mathrm{im} /$ article/view/2331

Pasaribu, A. M. (2017). Pendapatan Usaha dan Beban Operasional terhadap Laba Bersih pada Perusahaan Makanan dan Minuman. Jurnal Wira Ekonomi Mikroskil, 7(2), 173180. Diakses dari https://www.mikroskil.ac.id/ejurnal/ index.php/jwem/article/view/501/25 $\underline{0}$

Suryandari, D. M. (2018). Pengaruh Pendapatan Bagi Hasil Pembiayaan Mudarabah dan Musyarakah terhadap Laba Bersih pada PT Bank Syariah Bukopin, Tbk. Skripsi. IAIN Tulungagung. Diakses dari http://repo.iaintulungagung.ac.id/7647/ 